\title{
28. COAL PETROLOGICAL STUDIES OF SEDIMENTS FROM SITES 496, 499, AND 500, DEEP SEA DRILLING PROJECT LEG 67, MIDDLE AMERICA TRENCH AND SLOPE OFF GUATEMALA ${ }^{1}$
}

\author{
Monika Wolf, Lehrstuhl für Geologie, Geochemie und Lagerstätten des Erdöls und der Kohle, RWTH Aachen, \\ D-5100 Aachen, Federal Republic of Germany
}

\begin{abstract}
Dispersed organic matter of plant origin from three sites of the Middle America Trench transect was investigated by coal petrographic methods. Samples from the slope region are rich in lipoid and inert substances. Humic matter is predominant in the trench sediments. Reflectance measurements show that the rank of the organic matter is peat, independent of the tectonic position and age of the samples in question. A slow increase of coalification with depth is observed.
\end{abstract}

\section{INTRODUCTION}

Leg 67 samples, collected primarily for mineralogical investigations at the Ruhr Universität Bochum, contain some plant remains. This observation suggested that coalification studies should be added to the petrological program to obtain more information on the diagenesis of the sediments.

\section{METHOD}

The samples were washed with water, and the light particles floating on the water surface were collected, dried, and mounted in polyester. The plugs obtained were polished and investigated in incident white light. Besides foraminifers and other microfossils, some organic compounds, most of them of plant origin, were observed. This dispersed organic matter (DOM) is described in the following text.

\section{COMPOSITION OF THE DISPERSED ORGANIC MATTER}

The amount of DOM was very low as a rule. Most of the samples contained only a few particles of different origin. The approximate composition of DOM is compiled in Table 1. Liptinite consists of bitumens, resins, algal remains, and so on. The Huminite group contains Textinite and Ulminite (remains of nongelified and gelified tissues), Corpohuminite (former humic-cell fillings), Attrinite and Densinite (nongelified and gelified detrital humic matter), and amorphous humic substances. The Inertinite group contains oxidized remains of different origin. Partly the inerts are fungal remains and Fusinite of primary origin, partly they are reworked components. Whether oxidation of the organic matter is synsedimentary or the result of reworking could not be decided in every case, therefore, all the remains are grouped together. In some cases reworked particles of former coal seams (sub-bituminous and bituminous coal) are identified. They are counted separately because this observation may have paleogeographic implications.

\footnotetext{
${ }^{1}$ Aubouin, J., von Huene, R., et al., Init. Repts. DSDP, 67: Washington (U.S. Govt. Printing Office).
}

Table 1. Composition of dispersed organic matter (fauna excluded).

\begin{tabular}{|c|c|c|c|c|c|}
\hline \multirow{2}{*}{$\begin{array}{c}\text { Sample } \\
\text { (core-section, } \\
\text { interval in } \mathrm{cm} \text { ) }\end{array}$} & \multirow[b]{2}{*}{ Stratigraphy } & \multicolumn{4}{|c|}{ Content (vol. \%) } \\
\hline & & Liptinite & Huminite & Inertinite & $\begin{array}{c}\text { Fragments of } \\
\text { Seam Coal }\end{array}$ \\
\hline \multicolumn{6}{|l|}{ Site 496 , midslope } \\
\hline $1-1,10-12$ & Quaternary & 33 & 23 & 44 & - \\
\hline $10-2,10-12$ & Quaternary & 57 & - & 43 & - \\
\hline $13-1,16-18$ & Quaternary & 80 & - & 20 & - \\
\hline $16-1,39-41$ & Quaternary & - & 20 & 80 & - \\
\hline $20-2,43-45$ & Quaternary & 50 & 19 & - & 31 \\
\hline $23-4,36-40$ & Quaternary & 27 & 5 & 41 & 27 \\
\hline $27-4,14-16$ & lower Pliocene & 68 & - & 32 & - \\
\hline $35-2,56-58$ & lower Miocene & 90 & - & 10 & - \\
\hline $38-1,79-81$ & lower Miocene & 31 & 51 & 18 & - \\
\hline \multicolumn{6}{|c|}{ Site 499 , trench floor } \\
\hline $3-4,132-134$ & Quaternary & 38 & 38 & 24 & - \\
\hline $7-1,49-51$ & Quaternary & 2 & 26 & 72 & - \\
\hline $10-2,121-123$ & Quaternary & 16 & 58 & 24 & 2 \\
\hline $14-2,44-46$ & Quaternary & 5 & 93 & 2 & - \\
\hline $16-1,25-27$ & Quaternary & 100 & - & - & - \\
\hline \multicolumn{6}{|c|}{ Site 500 , trench floor } \\
\hline $9-1,53-55$ & Quaternary & 15 & 36 & 49 & - \\
\hline
\end{tabular}

Note: $-=$ not observed.

Table 1 shows the results of the maceral group analyses. The Site 496 Quaternary and Pliocene samples from the midslope contain mostly Liptinite and Inertinite. In contrast, the deepest lower Miocene sediment is rich in humic matter. Aboard ship, "small lignite bands" were noted in the corresponding depth interval. The observed DOM of this sample (496-38-1, 79-81 cm) may represent these small lignite bands. On the slope the influx of reworked material is remarkable (von Huene et al., 1980). The amount of reworked particles is higher than that of the original plant remains in some samples and complicates our recognizing those humic remains that represent the true coalification.

The samples of Sites 499 and 500 from the trench floor are characterized by high amounts of Huminite, whereas Liptinite is sometimes rare.

\section{COALIFICATION STUDIES}

Only a few humic particles could be used for coalification studies by reflectance measurements. Some of the 
particles belong to the dark variety (Textinite A, Ulminite A), which is not suitable for reflectance measurements (International Handbook of Coal Petrography, 1971). Other particles are too small. Therefore, particularly for Site 496, the results are the average of a small number of single readings. Random reflectance was determined using the Leitz Orthoplan with microscope photometer MPV1 equipped with a $50 \times 10,85 \mathrm{P}$ oil immersion objective. The method is described in detail in the International Handbook of Coal Petrography (1971).

The data (Table 2) show low reflectance values-corresponding to the peat stage-in the uppermost samples of all sites, independent of their geotectonic position. Near the Quaternary/Tertiary boundary a slow increase of coalification is observed at Site 496. However, even the lowest early Miocene sample yet contains peat-stage remains.

These results from the coalification studies are the same as described by Teichmuller (1968) from the nearly 200-meter-thick peat seam at Philippi (Greece). The peat was deposited in the Quaternary. She measured reflectance values between $0.14 \% \mathrm{Rm}($ depth $=1 \mathrm{~m})$ and

Table 2. Reflectance measurements.

\begin{tabular}{lrrr}
\hline $\begin{array}{c}\text { Sample } \\
\begin{array}{c}\text { (core-section, } \\
\text { interval in cm) }\end{array}\end{array}$ & $\overline{\mathrm{R}}_{\mathrm{r} \text { (oil) } \%^{\mathrm{a}}}$ & $\mathrm{n}^{\mathrm{b}}$ & $\mathrm{s}^{\mathrm{c}}$ \\
\hline Site 496, midslope & & & \\
& & & \\
$1-1,10-12$ & 0.15 & 7 & 0.03 \\
$16-1,39-41$ & 0.15 & 1 & - \\
$20-2,43-45$ & 0.20 & 5 & 0.03 \\
$23-4,36-40$ & 0.23 & 4 & - \\
$38-1,79-84$ & 0.22 & 17 & 0.03 \\
Site 499, trench floor & & & \\
& & & \\
$3-4,132-134$ & 0.15 & 8 & 0.02 \\
$7-1,49-51$ & 0.18 & 14 & 0.04 \\
$10-2,121-123$ & 0.19 & 29 & 0.04 \\
$14-2,44-46$ & 0.18 & 46 & 0.04
\end{tabular}

Site 500 , trench floor

$$
\begin{aligned}
& \begin{array}{llll}
9-1,53-55 & 0.16 & 9 & 0.03
\end{array} \\
& \text { a } \bar{R}_{r}=\text { average of random reflectance. } \\
& \mathrm{b} n=\text { number of measurements. } \\
& \mathrm{c}_{\mathrm{S}}=\text { standard deviation. }
\end{aligned}
$$

$0.22 \% \mathrm{Rm}^{2}$ (depth $\left.=178 \mathrm{~m}\right)$. Regardless of whether Quaternary plant accumulations are studied from the forelands of the Alps (Koch, 1966), from Greece, or now from the Middle America Trench transect off Guatemala, the peat/lignite transition has not yet been found to have occurred. One exception is known, however, from the northern part of West Germany, where lignite occurs in early Quaternary sediments and is explained by the high pressure exerted by the continental ice sheet (Brunnacker et al., 1975). Because of the weight of the overlying ice, the water was squeezed out and the peat was compressed; consequently, lignite was formed.

In comparison with results from coalification studies of the U.S. Gulf Coast (Teichmüller and Teichmüller, 1966), in which humic inclusions in claystones of the uppermost middle Miocene (encountered at a depth of 5440 meters) were found to have reached the stage of high volatile bituminous coal $(0.95 \% \mathrm{Rm})$, the Leg 67 studies yielded data that lead us to conclude that the lower Miocene sediments from Site 496, with their plant remains indicating the peat stage, were never exposed to increased temperatures.

On the whole, the Leg 67 coalification studies allow us to make two conclusions: At these sites, there is (1) a lack of a thick overburden, and (2) a low temperature gradient in the Middle America Trench transect off Guatemala.

\section{REFERENCES}

Brunnacker, K., Boenigk, W., Wolf, M., and Koči, A.,1975. Die Sedimente der Lieth-Serie bei Elmshorn. Geol. Jahrb., A26:153-171.

International Handbook of Coal Petrography (2nd ed., 1st supplement): 1971, Paris.

Koch, J., 1966. Petrologische Untersuchungen an jungpleistozänen Schieferkohlen aus dem Alpenvorland der Schweiz und Deutschlands mit Vergleichsuntersuchungen an holozänen Torfen [doctoral dissert.]. Technische Hochschule Aachen.

Teichmüller, M., 1968. Zur Petrographie und Diagenese eines fast 200 $\mathrm{m}$ mächtigen Torfprofils (mit Übergängen zur Weichbraunkohle?) im Quartar von Philippi (Mazedonien). Geol. Mitt., 8:65-110.

Teichmüller, M., and Teichmüller, R., 1966. Geological causes of coalification: coal science. Adv. Chem. Ser., 55:133-155.

von Huene, R., Aubouin, J., Azéma, J., Blackinton, G., Carter, J. A., Coulbourn, W. T., Cowan, D. S., Curiale, J. A., Dengo, C. A., Faas, R. W., Harrison, W., Hesse, R., Hussong, D. M., Ladd, J. W., Muzylöv, N., Shiki, T., Thompson, P. R., and Westberg, J., 1980. Leg 67: the Deep Sea Drilling Project Mid-America Trench transect off Guatemala. Geol. Soc. Am. Bull., 91, Pt. I:421-432.

\footnotetext{
${ }^{2} \mathrm{Rm}=$ mittlere Reflexion (random reflectance).
} 